\title{
Redaksjonelt
}

\section{FORMakademisk med støtte fra Norges forskningsråd}

Det var med stor glede redaksjonen mottok meldingen fra Norges forskningsråd om at FORMakademisk var innvilget produksjonsst $\varnothing t t e$ for Open-Access-tidsskrift for 2011. Det er første gang forskningsrådet gir publiseringsstøtte til nettbaserte tidsskrift, og vi ser på dette som en stor anerkjennelse for FORMakademisk.

Nettbasert publisering gir mange fordeler, ikke minst innen designforskning hvor bilder, også i farger, ofte er en nødvendig integrert del av de vitenskapelige artiklene. Slike illustrasjoner er en stor utgift i papirbaserte tidsskrift. Bruk av videoer i artikler, som i temanummeret Research by Design vol. 3 nr. 2, er en stor fordel for FORMakademisk. Det hadde faktisk ikke vært mulig om vi publiserte på papir.

Men også drift av et nettbasert tidsskrift som FORMakademisk krever økonomiske ressurser. Noen institusjoner har bidratt mer enn andre for å gjøre utgivelsen av FORMakademisk mulig, i form av både arbeidstid og driftsmidler. Dette gjelder ikke minst Høgskolen i Oslo, hvor Storbyprogrammet står i en særstilling når det gjelder dette. Andre har hittil mest nytt godt av godet det er å ha et tidsskrift innen designforskning for å oppnå vitenskapelig publisering, og dermed publiseringspoeng, som igjen tilfører utdanningsinstitusjonene $\varnothing$ konomiske midler.

Vi regner derfor med at både utdanningsinstitusjoner, interesseorganisasjoner og andre ser tildelingen fra Norges forskningsråd som en anerkjennelse av FORMakademisk som vitenskapelig tidsskrift $o g$ som en inspirasjon til å i større grad bidra $\emptyset$ konomisk i den videre driften av FORMakademisk i de kommende år.

I dette første nummeret $\mathrm{i}$ årgang 4 av FORMakademisk fortsetter vi tradisjonen vi startet $\mathrm{i}$ forrige nummer med å publisere artiklene etter hvert som de er klare for publisering. Også i dette nummeret vil artiklene spenne over et stort lerret innen designforskning.

De tre første artiklene i dette nummeret har alle arkitektur som utgangspunkt, men på svært ulike vis. Michael U. Hensel skriver om performance-orientert design innen arkitektur, med fokus på interaksjonen mellom de fire dimensjonene romlig og materiell organisering, det menneskelige subjekt og miljøet. For å undersøke denne interaksjonen, er det også nødvendig å undersøke disse faktorene hver for seg. Drøftingene er supplert med eksempler i form av research-by-design.

Erlend Vinje gir en diskursanalyse av mediatekster på internett om utformingen av skoleanlegg i form av baseskoler. Analysen viser at skoleeiere og skoleledere oftest argumenter for baseskoler, mens lærere, foreldre og forskere i hovedsak støtter den tradisjonelle skolen. Forfatteren argumenterer for at utbygging av baseskoler kan skyldes strukturelle strategier for å drive administrasjon av skoler enklere og billigere. 
Joar Skrede analyserer argumentene for relokaliseringen av mange kulturinstitusjoner i Oslo, med de kritiske røstene som et bakteppe. Den kritiske diskursanalysen viser at kritikerne $\emptyset$ nsker å bevare de gamle bygningene fordi de rommer nasjonens kollektive minne, mens tilhengerne argumenterer for at de nye bygningene vil være brikker i et større fornyingsprosjekt som vil gi en synergieffekt langt ut over funksjonen som kulturorganisasjoner. Artikkelen konkluderer med at $\varnothing$ konomiens inntog i den kulturelle sfære kan være en trussel mot kulturarven.

Biljana C. Fredriksen hevder i sin artikkel at prosessen med meaning-making, eller meningsdannelse, er nært knyttet til legemliggjort erfaring og sosial interaksjon. Artikkelen er basert på en studie av barn i alderen 3-5 år sin lek med 3-dimensjonale materialer, og interaksjonen mellom barna og en forsker som samtidig er praktiker innen feltet. Forfatteren konkluderer med at barnas nye forståelser komme fra "møter" mellom deres fortid og deres nye erfaringer, stimulert av de 3-dimensjonale materialenes muligheter og motstand.

Mari Rorgemoen har skrevet en artikkel med bakgrunn i problematikk omkring utvikling av forskingsbasert didaktikk for tekstilundervisning innen folkekunst. Undersøkelsen er basert på intervjuer av studenter og analyse av deres oppgaverapporter, drøftet på grunnlag av sosiokulturell og sløydpedagogisk teori, i møte med folkekunst. Drøftingen viser at kopiering som læringsmetode har en plass i en forskingsbasert didaktikk når virksomheten fører til erkjenning og integrert forståing, ikke som rekonstruksjon av tradisjoner.

Magnus Rönn sin artikkel er resultatet av en omfattende studie av arkitektkonkurranser i de nordiske landene (1999-2000). Undersøkelsen er basert på intervjuer med erfarne jurymedlemmer, som representerer klienter, arkitekter og arkitektorganisasjoner. Studien refererer til kvalitet som et nøkkel-begrep når det gjelder å bedømme og velge en prisvinner. Forfatteren hever at det er mulig å artikulere hvordan arkitektonisk kvalitet blir kommunisert av jurymedlemmene, og hvordan en vinner blir nominert. Kompetanse og konsensus er to viktige faktorer som gjør at jurymedlemmer føler seg trygge i sitt endelige valg av en vinner i arkitektkonkurranser.

Som i det forrige nummeret, er denne lederen oppdatert etter hvert som artikler er publisert i løpet av våren 2011.

Oslo, juni 2011

Janne Beate Reitan

Ansvarlig redaktør 